\title{
КОМУНІКАТИВІСТИКА ЯК ЗАГРОЗА ЖУРНАЛІСТИЦІ
}

\author{
Василь ЛИЗАНЧУК \\ д-р філол. н., заслужений \\ професор \\ Львівський національний \\ університет імені Івана Франка \\ вул. Генерала Чупринки, 49 \\ 79001, Львів, Україна \\ e-mail:vvlyzanchuk@gmail.com \\ (c) Лизанчук В., 2018
}

Під гаслом так званого реформування галузі знань кафедра журналістики та нових медій Інституту журналістики Київського університету імені Бориса Грінченка, кафедра міжнародних медіакомунікацій та комунікативних технологій Інституту міжнародних відносин Київського національного університету імені Тараса Шевченка та громадська організація «Національна академія комунікативістики» на круглому столі «Впровадження в Україні освітньої галузі «Комунікативістика» задекларували переіменувати галузь знань 06 «Журналістика» на 06 «Комунікативістика».

\section{COMMUNICATIVISTICS AS A THREAT TO JOURNALISM}

\author{
Vasyl Lyzanchuk \\ Doctor of Philology \\ Honoured Professor \\ Ivan Franko Lviv National University \\ 49 General Chuprynka Str., 79001, Lviv, Ukraine \\ e-mail:vvlyzanchuk@gmail.com
}

Under the slogan of the so-called education reformation, during round-table discussion "Introduction of education branch "Communicativistics" in Ukraine" the Chair of journalism and new media of Institute of Journalism of Borys Hrynchenko Kyiv University, the Chair of international mediacommunications and communicative technologies of International Relations Institute of Taras Shevchenko Kyiv National University and public organization "National Academy of Communicativistics" declared renaming of education branch 06 "Journalism" into 06 "Communicativistics".

Розповсюдили розгорнуту «Пояснювальну записку», в якій засобами маніпуляції «переконують», що, мовляв, галузь знань «06 Журналістика» не здатна охопити широкий спектр різних форм та видів суспільних відносин, предметом яких є комунікативна взаємодія 
між суб'єктами. Підготовлено також проект постанови Кабінету Міністрів України, в якому запропоновано викласти позицію «06 Журналістика» в такій редакції: «06 Комунікативістика, 061 Комунікації і журналістика».

Якщо цей проект як постанову підпише Прем’єр-міністр України В. Гройсман, то журналістику відкинуть на задвірки, перекреслять сутність ї̈ як провідного соціального інституту, метою якого є забезпечення правдивого, всебічного та об'єктивного інформування суспільства про соціальну дійсність на засадах україноцентризму, формування в людей державницького мислення як мислення національно-гуманного, демократичного, правового, громадянського, відповідального за особисту долю, долю родини, долю України. Журналістика як суспільне, політичне, культурне явище $є$ дуже важливим засобом для підтримки оптимального функціонування інших соціальних інститутів й українського суспільства загалом. За своїми природними властивостями журналістика здатна забезпечити всі потреби комунікативістики.

Перетворення галузі знань «06 Журналістика» на галузь знань «06 Комунікативістика» зводить нанівець функції журналістики, до яких належать інформування, вираження й формування громадянської думки, просвітницька пропаганда, виховна, естетична, розважальна, інтегруюча, агітаційно-організаторська тощо. Свідомо чи підсвідомо так звані реформатори хочуть звести українську національну журналістику лише до статусу спілкування, комунікування. За комуністичного режиму постійно нав'язували тезу, що мова - це засіб спілкування, комунікування, перекреслюючи не менш важливі функції: ідентифікаційну, експресивну, гносеологічну, мислетворчу, естетичну, культуроносну, номінативну тощо. Комуністичні ідеологи-маніпулятори боялися того, що українці зрозуміють: українська мова - це дім буття, духовна, світоглядна, націєтворча категорія. Під гаслом «какая разница на каком языке говорить» цілеспрямовано зросійщували українців, національні меншини.

Нинішні маніпулятори хочуть звести українську національну журналістику лише у засіб звичайного комунікування. Наголошую: не треба спекулювати на тому, що у світовій практиці найбільш поширеним напрямом освіти у сфері медіа та комунікацій $є$ напрям Communications and Media Study або ж Communications Study, що українською перекладають як «Комунікативістика».

Невже ви, ініціатори перетворення «06 Журналістики» на «06 Комунікативістику», не знаєте, що триває жорстока російсько-українська війна, що інформаційно-психологічна агресія Російської Федерації проти України набирає найпідступніших форм і методів, що гібридна війна Росії охопила також всю Європу? 
У таких неймовірно важких умовах боротьби за соборну українську державу українську національну журналістику треба всіляко зміцнювати, поглиблювати, розширювати, готувати у навчальних закладах національно свідомих журналістів, а не скочуватися до космополітичного комунікування, маніпулятивного реформування галузі знань «06 Журналістика».

Доречно нагадати, що журналістика - це складна, цілеспрямована, динамічна суспільно важлива система, що охоплює періодичні друковані видання, радіомовлення, телебачення, Інтернет, інформаційні агентства, різноманітні форми комунікації. Специфіка кожного зі складових журналістики визначається, передусім, за такими критеріями: способом передачі інформації, характером виражальних засобів, особливістю і якістю каналу інформування, своєрідністю сприймання контенту на засадах україноцентризму. Природне покликання журналістики реалізовується через правдиве друковане й усне слово, зображення, акустичну характеристику подій.

Звернімося до підручників засновників нашого журналістикознавства - «Теорія і практика журналістської творчості» Д. М. Прилюка, «Теорія і методика журналістської творчості» В. Й. Здоровеги, «Основи журналістики» А. З. Москаленка. Прочитаймо праці сучасних теоретиків і практиків журналістики - А. А. Бойко, О. Я. Гояна, 3. Є. Дмитровського, М. Г. Житарюка, І. В. Крупського, С. А. Костя, I. Л. Михайлина, Б. В. Потятиника, В., М. С. Тимошика, В. І. Шкляра, А. В. Яковця та багатьох інших учених. У них, зокрема, йдеться й про те, що виражальні засоби журналістики повністю охоплюють потреби комунікативістики. Тож не треба воза ставити перед конем! Саме цього хоче Московія-Росія - одвічний ворог Русі-України!

Якщо добродіям - Олегові Шарову, Олексію Тарабукіну, Сергію Даниленкові, Леонідові Новохатьку та іншим хочеться створити нову галузь знань - «Комунікативістику», то воля ваша - створюйте, але не перекреслюйте багатовікову галузь знань «06 Журналістику», потреба у якій нині зростає.

Безперечно, маємо поліпшувати науково-педагогічні методи й форми підготовки журналістів, поглиблювати інтелектуально-технічні умови функціонування засобів масової комунікації, а не під гаслом реформування знищувати журналістику як соціальну інституцію, перетворювати її на вузький засіб комунікування - комунікативістику.

У нинішніх умовах глобалізаційних процесів, російсько-української війни, цілеспрямованих інформаційно-психологічних загроз Україні здоровий глузд вимагає грунтовного зміцнення української національної журналістики. Ця проблема може бути предметом дискусії, а не питання - бути чи не бути українській журналістиці, бути чи не бути Українській Державі. 
Архіважливу думку висловив доктор філологічних наук, професор, один з найпотужніших фахівців із комунікативних технологій, інформаційних воєн та протидії інформатакам й операціям впливу московської маніпулятивної пропаганди Георгій Почепцов: «Поки що маємо публіцистичні реакції на події. Для того, щоб сталося мистецьке переосмислення, відбувається публіцистичне, журналістське. Саме журналістські постаті нині найкраще працюють з масовою свідомістю». Отже, не комунікативісти, а журналісти, публіцисти є потужною морально-духовною, національно-громадянською силою! Тому не знищуйте галузь знань «06 Журналістика»!

Чи знають про цю справжню приховану форму ліквідації журналістикознавчого навчального процесу, знищення української національної журналістики Президент України, голова Верховної Ради України, Прем'єр-міністр України, Міністр освіти і науки України, видатні вчені, педагоги Інституту журналістики Київського національного університету імені Тараса Шевченка, факультету систем і засобів масової комунікації Дніпровського національного університету імені Олеся Гончара, Інституту журналістики та масової комунікації Класичного приватного університету (м. Запоріжжя), факультету журналістики Міжнародного економіко-гуманітарного університету імені академіка Степана Дем'янчука (м. Рівне), факультету журналістики, реклами та видавничої справи Одеського національного університету імені I. I. Мечникова, кафедри журналістики Харківського національного університету імені Каразіна, кафедри журналістики Національного університету «Острозька академія», кафедри журналістики та філології Сумського державного університету, викладачі інших навчальних закладів, національно свідомі журналісти, громадськість України?!

Рятуймо галузь знань «06 Журналістика»!!! 